Article

\title{
Application of Growth Activators and Plant Growth-Promoting Rhizobacteria as a Method of Introducing a "Farm to Fork" Strategy in Crop Management of Winter Oilseed
}

\author{
Arkadiusz Artyszak *(D) and Dariusz Gozdowski (D) \\ Institute of Agriculture, Warsaw University of Life Sciences-SGGW, 02-776 Warsaw, Poland; \\ dariusz_gozdowski@sggw.edu.pl \\ * Correspondence: arkadiusz_artyszak@sggw.edu.pl; Tel.: +48-22-5932702
}

Citation: Artyszak, A.; Gozdowski, D. Application of Growth Activators and Plant Growth-Promoting Rhizobacteria as a Method of Introducing a "Farm to Fork" Strategy in Crop Management of Winter Oilseed. Sustainability 2021, 13, 3562. https://doi.org/10.3390/su13063562

Academic Editor: Silvia Tabacchioni

Received: 15 February 2021

Accepted: 20 March 2021

Published: 23 March 2021

Publisher's Note: MDPI stays neutral with regard to jurisdictional claims in published maps and institutional affiliations.

Copyright: (C) 2021 by the authors. Licensee MDPI, Basel, Switzerland. This article is an open access article distributed under the terms and conditions of the Creative Commons Attribution (CC BY) license (https:// creativecommons.org/licenses/by/ $4.0 /)$.

\begin{abstract}
In the European Union, out of concern for the quality of the natural environment, agriculture aims to limit the doses of mineral nitrogen to mitigate nitrogen leaching into the groundwater and $\mathrm{N}_{2} \mathrm{O}$ emissions into the atmosphere. This requires a search for new crop management for more environmentally friendly production. The aim of the study was to evaluate crop management technologies that would allow farmers to obtain high yields without high doses of nitrogen fertilizers. The study was conducted in Poland in 2016-2017 and 2018-2019 to test the effects of growth activators without an additional product and with a product containing plant growth-promoting rhizobacteria in the production of winter oilseed rape, reducing the nitrogen dose by $30 \%$. The results obtained in the study show a positive effect of the studied treatments on seed yield, which was higher by 9.8 and $7.7 \%$, and fat yield, higher by 11.4 and $9.2 \%$, respectively, compared to those for the control treatment in which the full nitrogen dose was applied. Taking into account the scale of oilseed rape production in Poland, this means savings of 52.8 thousand tonnes of mineral nitrogen per year. Therefore, introducing the researched solutions into agricultural practice would lead to measurable benefits for the natural environment.
\end{abstract}

Keywords: growth activator; nitrogen fertilization; plant growth-promoting rhizobacteria (PGPR); winter oilseed rape

\section{Introduction}

Oilseed rape is the main oilseed plant in the northern part of Europe, with a dominant winter form. The winter form has a higher yield potential than the spring form due to its longer growing season and lower sensitivity to spring droughts. Unfortunately, sometimes the winter form is damaged by frost. In 2019, oilseed rape occupied 5.65 million ha in the EU (28 countries), of which 0.88 million ha were in Poland, making it the third highest crop production in the EU after France and Germany [1].

The most important nutrient in the crop management of oilseed rape is nitrogen, which is necessary for the proper growth and development of plants. Oilseed rape consumes $50 \mathrm{~kg}$ of nitrogen for the production of 1 tonne of seed with the appropriate secondary crop, and the maximum amount of nitrogen available in the cultivation of this plant in accordance with the national and EU law in Poland is $240 \mathrm{~kg} \mathrm{~N} \mathrm{ha}^{-1}$ [2].

One of the main problems in EU agriculture is groundwater and air pollution caused by abundant mineral nitrogen fertilization. It is necessary to limit the doses of nitrogen fertilizers in rapeseed crop management in the near future to avoid nitrate leaching and $\mathrm{N}_{2} \mathrm{O}$ emissions from agricultural land [3-5].

Plant growth-promoting rhizobacteria (PGPR) can be successfully used to improve plant growth [6-14]. The beneficial effects of using preparations containing PGPR in the cultivation of oilseed rape (canola) were noted in many experiments [15-23]. Canola plants to which PGPR was applied were less susceptible to Brevicoryne brassicae L. [24]. 
Experimental results have proved the possibility of limiting nitrogen fertilization with oilseed rape by using PGPR $[25,26]$. PGPR allow increased production in a sustainable way and are the best alternative to mineral fertilizers [27-29].

An innovative and environmentally safe method of increasing yield is the use of Penergetic growth activators, which have been shown to cause increased yield of maize [30], cereals [31,32], sugar beet [33,34], potato [35], soybean [36], legumes [31,37-39] and coffee [40]. Results of studies on the use of Penergetic growth activators in the cultivation of oilseed rape are not available.

The aim of the experiment was to check whether it is possible to increase the seed yield and fat content in seeds of winter oilseed rape using a dose of mineral nitrogen reduced by $30 \%$ and replacing it with growth stimulants (growth activators) alone or together with a preparation containing PGPR (such as Azotobacter chroococcum, Azospirillum brasilense, and Bacillus megaterium).

\section{Materials and Methods}

\subsection{Study Area}

In the 2016-2017 and 2018-2019 seasons, field trials consisting of 10 individual experiments with winter rapeseed were performed: 3 in 2016-2017 (Sahryń, 50 $41^{\prime}$ N 23 $47^{\prime}$ E,

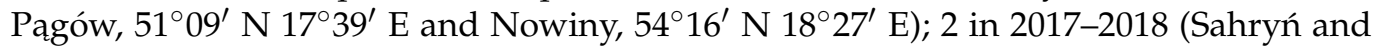
Pagów); and 5 in 2018-2019 (Sahryń and Pagów (2), and Nowiny and Pityny, 54 01' N $20^{\circ} 06^{\prime}$ E) (Figure 1). The soil of the experimental fields consisted of Calcic Chernozem (silty clay loam: 34\% clay, 14\% sand, 52\% silt) in Sahryń; Albic Podzols (soil texture class sandy loam with soil fraction content of 10\% clay, 55\% sand, 35\% silt) in Pagów; Endocalcaric Cambisol (soil texture class sandy loam with soil fraction content of $11 \%$ clay, $70 \%$ sand, $19 \%$ silt) in Nowiny; and Endocalcaric Cambisol (soil texture class sandy loam with soil fraction content of $12 \%$ clay, $64 \%$ sand, $24 \%$ silt) in Pityny [ 41$]$.

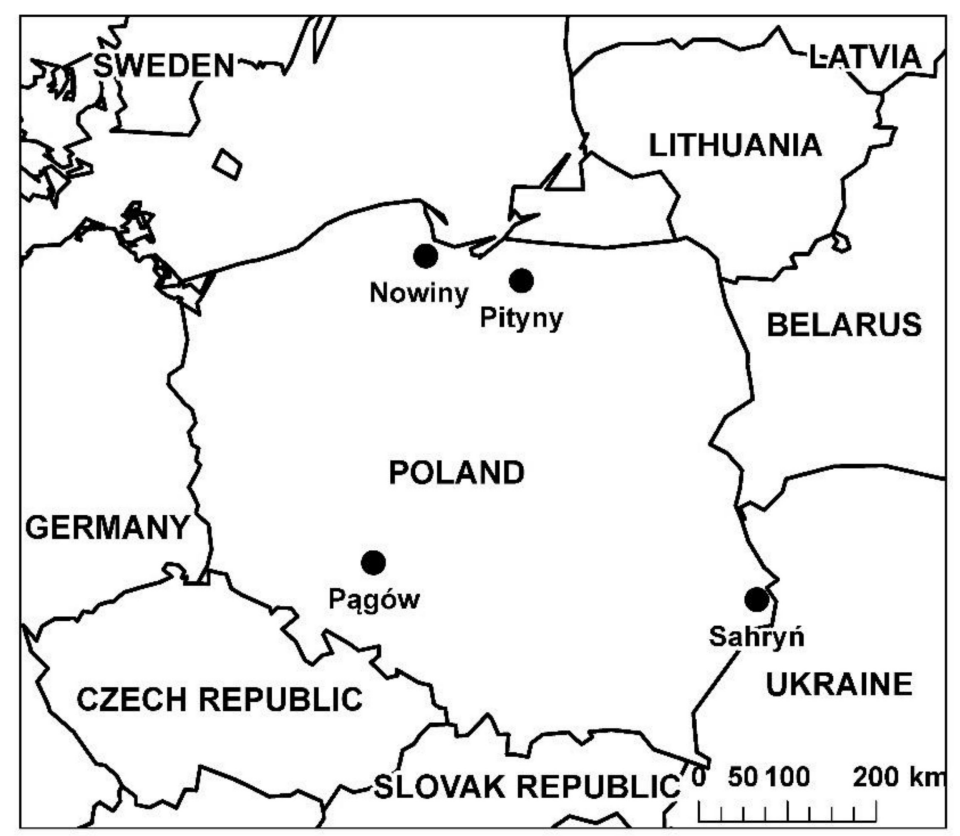

Figure 1. Locations of field experiments.

\subsection{Soil Sampling and Analysis}

After harvesting, forecrop soil samples at depths of 0-30 and 30-60 cm were collected. The second soil sampling was conducted after the winter rapeseed harvest at the same soil layers. Chemical analyses were conducted at chemical and agricultural stations in Poland according to standard procedures used for agricultural soils. Soil reaction $\left(\mathrm{pH}_{\mathrm{KCl}}\right)$ was measured potentiometrically in $1 \mathrm{M} \mathrm{KCl}$ [42]. Soil organic carbon (SOC) content [43] and 
nutrients available for plants, including nitrate nitrogen $\left(\mathrm{N}-\mathrm{NO}_{3}\right)$ and ammonium nitrogen $\left(\mathrm{NH}_{4}\right)$ [44], phosphorus (P) [45], potassium (K) [46], magnesium (Mg) [47], boron (B) [48], copper $(\mathrm{Cu})$ [49], iron (Fe) [50], manganese (Mn) [51] and zinc ( $\mathrm{Zn})$ [52] were analyzed according to standard procedures.

The soil $\mathrm{pH}$ before the sowing of winter rapeseed was adjusted to neutral or alkaline, i.e., favorable for rapeseed, except in Nowiny (30-60 cm layer) in 2016, Pagów (both layers) in 2017 and Pityny (0-30 cm layer) in 2018 (Table S1). Soil in most of the locations was characterized by relatively low SOC content, except Sahryń in 2016, when SOC content was high. The most important nutrients for rapeseed such as mineral nitrogen and available forms of phosphorus and potassium before sowing were at sufficient levels for proper growth and development of plants.

\subsection{Experimental Design and Treatments}

In the study, the weather conditions were limited to the spring-summer growing season (March-July). The amount of rainfall in this period was 259-404 mm in 2017, 304-419 $\mathrm{mm}$ in 2018 and 203-334 $\mathrm{mm}$ in 2019 (Table S2). The forecrop for winter rapeseed was, in most cases, winter wheat, and less often, spring wheat and spring barley (Table S3). The doses in the experiments were $10-69 \mathrm{~kg} \mathrm{P} \mathrm{ha}^{-1}$ of phosphorus, $22-125 \mathrm{~kg} \mathrm{~K} \mathrm{ha}^{-1}$ of potassium and $3-72 \mathrm{~kg} \mathrm{~S}^{-1}$ of sulphur. Total phosphorus and potassium were used before sowing winter oilseed rape. In spring, nitrogen was used in 2 doses: at the start of vegetation and up to 3 weeks later. Sulphur was introduced with the first dose of nitrogen in the spring. Before sowing winter oilseed rape, small amounts of nitrogen and sulphur were supplied with compound fertilizers. Depending on the location, the nitrogen mineral fertilizers were applied as urea ammonium nitrate or a mixture of these two forms. Potassium and phosphorus were applied as mineral fertilizers in forms available for plants (mainly potassium chloride and superphosphate). Foliar fertilizers containing boron were applied in the fall and spring. Plant protection against pests (including weeds, diseases and insects) was conducted according to standard methods recommended by official plant protection services in Poland.

In the experiment, 3 treatments were applied (Table 1).

Table 1. Description of experimental treatments.

\begin{tabular}{|c|c|}
\hline Treatment & Characteristics \\
\hline 0 & $\begin{array}{l}\text { Control: Standard nitrogen mineral fertilization rate, which, adjusted for soil } \\
\text { properties and depending on location, was in the range of } 139-258 \mathrm{~kg} \mathrm{ha}^{-1} \mathrm{~N} \text {. }\end{array}$ \\
\hline 1 & $\begin{array}{l}\text { Mineral nitrogen fertilization reduced by } 30 \% \text { compared to standard dose } \\
\text { (treatment } 0 \text { ) before planting and during growth of rapeseed (first dose of } \\
\text { nitrogen in spring was the same as in treatment } 0 \text {, second dose was reduced) at } \\
97 \text { to } 181 \mathrm{~kg} \mathrm{ha}^{-1} \mathrm{~N} \text {; Penergetic-K at } 400 \mathrm{~g} \text { per ha after forecrop harvest, before } \\
\text { soil tillage; Penergetic-K at } 400 \mathrm{~g} \text { per ha with first crop protection spraying in } \\
\text { spring; Penergetic-P at } 300 \mathrm{~g} \text { per ha with second crop protection spraying in } \\
\text { spring; Penergetic-P at } 300 \mathrm{~g} \text { per ha } 3 \text { weeks later. }\end{array}$ \\
\hline 2 & $\begin{array}{l}\text { Mineral nitrogen fertilization reduced by } 30 \% \text { compared to standard dose } \\
\text { (treatment } 0 \text { ) before planting and during growth of rapeseed (first nitrogen rate } \\
\text { in spring was the same as in treatment } 0 \text {, second dose was reduced) at } 97 \text { to } \\
181 \mathrm{~kg} \mathrm{ha}^{-1} \mathrm{~N} \text {; Penergetic-K at } 400 \mathrm{~g} \text { per ha }+ \text { Azoter at } 10 \mathrm{dm}^{3} \text { per ha after } \\
\text { forecrop harvest before soil tillage; Penergetic-K at } 400 \mathrm{~g} \text { per ha }+ \text { Azoter at } \\
10 \mathrm{dm}^{3} \text { per ha with first crop protection spraying in spring; Penergetic-P at } \\
300 \mathrm{~g} \mathrm{ha}^{-1} \text { with second crop protection spraying in spring; Penergetic-P at } \\
300 \mathrm{~g} \mathrm{dm}^{3} \text { per ha } 3 \text { weeks later. }\end{array}$ \\
\hline
\end{tabular}

Penergetic-K and Penergetic-P are growth activators produced by Penergetic International AG Company. The detailed composition of the products is reserved by the producer. Penergetic-K and -P are based on bentonite clay treated by electric and magnetic fields. Azoter is a preparation produced by Azoter Trading s.r.o. that contains plant growth- 
promoting rhizobacteria (PGPR). The $\mathrm{pH}$ of the product is in the range of 5.8 to 8.5 . The preparation contains the following microorganisms: Azotobacter chroococcum, Azospirillum brasilense and Bacillus megaterium. The total number of living microorganisms is at least $4 \times 10^{9}$ colony-forming units per $\mathrm{cm}^{-3}$. The application was as a water solution at a dose of $250 \mathrm{dm}^{3}$ per ha. The experiment in every location in every year was a randomized complete block design (RCBD) with 4 replications and 12 plots in each individual experiment. The number of individual experiments was 3, 2 and 5 in the 2016-2017, 2017-2018 and 2018-2019 seasons, respectively.

\subsection{Plant Sampling and Measurements}

Before harvest, plants were cut from a representative area of $15 \mathrm{~m}^{2}(3 \times 5 \mathrm{~m})$ from each plot and their density was determined. Ten plants were randomly selected from each sample, and the plant height and number of pods per plant were determined. The number of seeds was determined in 10 randomly selected pods from each plant. Then, all the plants were threshed, the seeds were cleaned of impurities and the seed and straw yields were weighed. The humidity of seeds was measured with an electric hygrometer (Dramiński GMM mini). Determination of raw fat content was carried out according to the PN-76/R-64753 [53] standard at the Chemical and Technological Laboratory of the Variety Evaluation Experimental Station in Słupia Wielka. Fat yield was calculated from the following formula: dry matter yield of seeds (at $9 \%$ moisture $\times 0.91) \times$ fat content in the location/100. The weight of 1000 seeds was determined at the Department of Agronomy at the Warsaw University of Life Sciences according to PN-EN ISO 520: 2010 [54].

The following measurements were performed in the experiments: seed yield at $9 \%$ moisture $\left(\mathrm{t} \mathrm{ha}^{-1}\right)$, seed moisture (\%), fat content in seeds (\% d.m.), fat yield $\left(\mathrm{kg} \mathrm{ha}^{-1}\right)$, straw yield $\left(\mathrm{t} \mathrm{ha}^{-1}\right)$, plant density at harvest $\left(\mathrm{pcs} . \mathrm{M}^{-2}\right)$, number of pods (pcs. Plant $\left.{ }^{-1}\right)$, number of seeds per pod (pcs.), weight of 1000 seeds (g) and plant height $(\mathrm{cm})$.

\subsection{Statistical Analysis}

For statistical analysis, ANOVA was performed with Tukey's procedure of multiple comparisons (honestly significant difference (HSD) test) at the 0.05 significance level. Individual experiments were treated as individual environments which varied by weather and soil conditions. Environment (location $\times$ year) was treated as the first factor with 10 levels (10 individual experiments) and treatment was the second factor with three levels. Due to this, two-way ANOVA was applied instead of three-way ANOVA, since all locations were not included in all years (site and year were not evaluated as separate factors, but together as environment).

Statistical analysis was conducted using Statistica 13 (TIBCO Software Inc., Palo Alto, CA, USA). The results were presented using descriptive statistics, including range (minmax), means and parameters of variability (standard deviation (SD) and coefficient of variation $(\mathrm{CV}))$.

\section{Results}

\subsection{Comparisons of Soil Properties}

The impact of the applied experimental fertilizer combinations on selected soil properties was observed primarily in Pagów in 2018 and 2019, when the forecrop was winter wheat (Table S4). In some locations, a positive effect of combination 1 on increased content of ammonium nitrogen $\left(\mathrm{N}-\mathrm{NH}_{4}\right), \mathrm{K}$, nitrate nitrogen $\left(\mathrm{N}-\mathrm{NO}_{3}\right)$, mineral nitrogen (Nmin), $\mathrm{Mn}$ and $\mathrm{Zn}$ in the soil was observed in relation to the control treatment (0). In the case of combination 2, increased content was found for nitrate nitrogen $\left(\mathrm{N}-\mathrm{NO}_{3}\right), \mathrm{Mn}$, ammonium nitrogen $\left(\mathrm{N}-\mathrm{NH}_{4}\right)$, mineral nitrogen (Nmin), $\mathrm{B}, \mathrm{K}$ and $\mathrm{Zn}$ (Table S4).

\subsection{Comparisons of Plant Traits}

For treatment 1, significant increases in seed yield (by 9.8\%), fat content in seeds (by $1.3 \%$ ), fat yield (by $11.4 \%$ ), number of pods per plant (by 12.5\%), number of seeds per pod 
(by $8.7 \%$ ) and plant height (by $2.1 \%$ ), and a significant reduction in the weight of 1000 seeds (by $5.9 \%$ ) were observed compared to treatment 0 (Table 2, Figure 2).

Table 2. Comparison of means for pooled data (all years and locations) based on ANOVA and multiple comparisons by Tukey's highly significant difference (HSD) test. $p$-values show the influence of studied treatments on yield and traits of winter rapeseed (2017-2019) and main effects of factors (location $\times$ year) and their interactions.

\begin{tabular}{|c|c|c|c|c|c|c|}
\hline \multirow[b]{2}{*}{ Trait } & \multicolumn{3}{|c|}{ Treatment } & \multicolumn{3}{|c|}{$p$-Value Based on ANOVA } \\
\hline & 0 & 1 & 2 & $\begin{array}{l}\text { Treatment } \\
\text { (T) }\end{array}$ & $\begin{array}{c}\text { Environment } \\
(\mathrm{E}: \text { Year } \times \text { Location })\end{array}$ & $\begin{array}{l}\text { Interaction: } \\
\quad \mathrm{T} \times \mathrm{E}\end{array}$ \\
\hline Seed yield at $9 \%$ moisture $\left(t \mathrm{ha}^{-1}\right)$ & $3.77 \mathrm{a}^{1}$ & $4.14 \mathrm{~b}$ & $4.06 \mathrm{~b}$ & $<0.001$ & $<0.001$ & 0.001 \\
\hline Seed moisture $(\%)$ & $7.87 \mathrm{a}$ & $7.97 \mathrm{ab}$ & $8.14 b$ & $<0.001$ & 0.041 & $<0.001$ \\
\hline Fat content in seeds (\% d.m.) & $45.98 \mathrm{a}$ & $46.58 \mathrm{~b}$ & $46.67 \mathrm{~b}$ & $<0.001$ & $<0.001$ & $<0.001$ \\
\hline Fat yield $\left(\mathrm{kg} \mathrm{ha}^{-1}\right)$ & $1584 \mathrm{a}$ & $1764 \mathrm{~b}$ & $1730 \mathrm{~b}$ & $<0.001$ & $<0.001$ & 0.002 \\
\hline Straw yield $\left(\mathrm{t} \mathrm{ha}^{-1}\right)$ & $3.97 \mathrm{~b}$ & $3.83 \mathrm{ab}$ & $3.75 \mathrm{a}$ & $<0.001$ & 0.032 & $<0.001$ \\
\hline Plant density at harvest (pcs. $\mathrm{m}^{-2}$ ) & $32.39 \mathrm{a}$ & $32.52 \mathrm{a}$ & $32.70 \mathrm{a}$ & $<0.001$ & 0.787 & 0.146 \\
\hline Number of pods (pcs. plant ${ }^{-1}$ ) & $288.5 \mathrm{a}$ & $324.5 \mathrm{~b}$ & $310.8 \mathrm{ab}$ & $<0.001$ & 0.027 & $<0.001$ \\
\hline Number of seeds per pod (pcs.) & $22.11 \mathrm{a}$ & $24.04 \mathrm{~b}$ & $25.94 \mathrm{c}$ & $<0.001$ & $<0.001$ & $<0.001$ \\
\hline Weight of 1000 seeds $(\mathrm{g})$ & $4.89 \mathrm{~b}$ & $4.60 \mathrm{a}$ & $4.76 \mathrm{~b}$ & $<0.001$ & 0.001 & $<0.001$ \\
\hline Height of plants (cm) & $140.8 \mathrm{a}$ & $143.8 \mathrm{~b}$ & $143.1 \mathrm{ab}$ & $<0.001$ & 0.109 & $<0.001$ \\
\hline
\end{tabular}

${ }^{1}$ Different letters within rows indicate significant differences between means at $\alpha=0.05$.

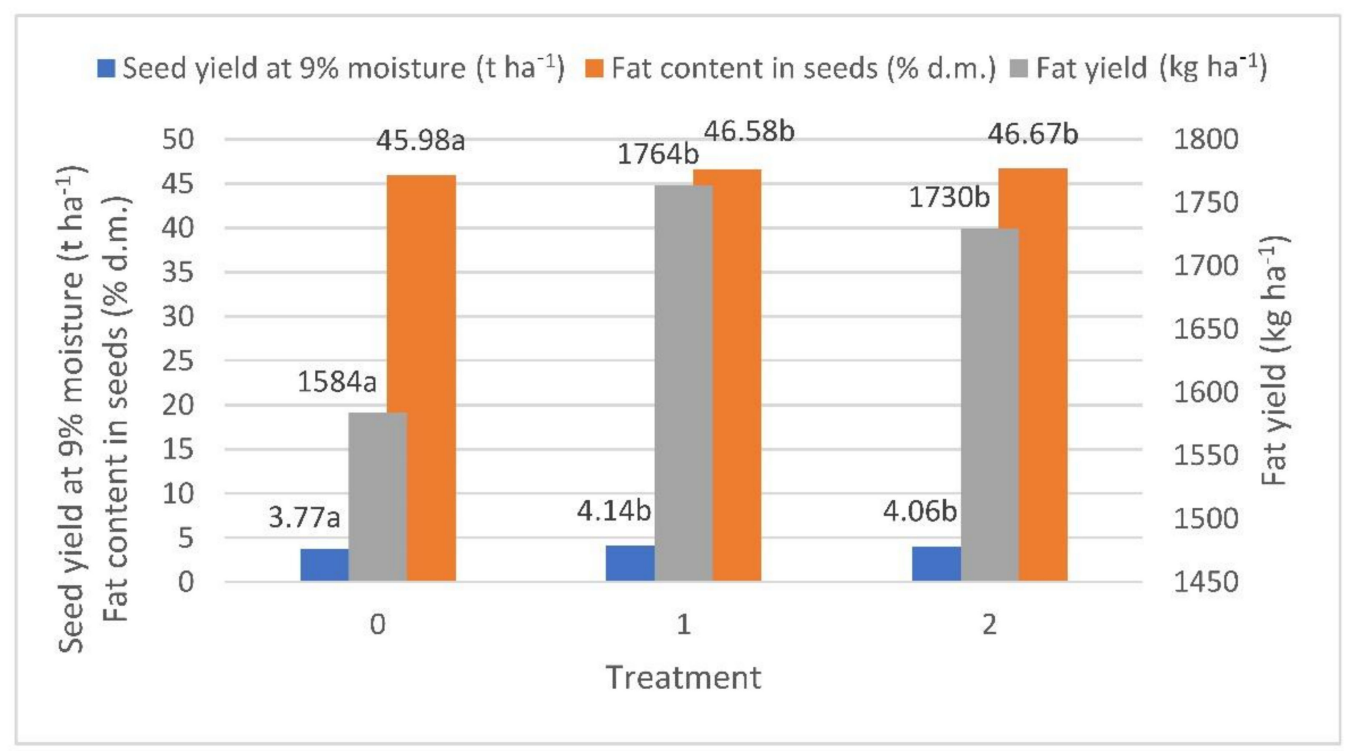

Figure 2. Means of seed yield, fat content and fat yield after treatment of winter oilseed rape in 2017-2019. (Same letters under columns in same color indicate no significant difference between means at $\alpha=0.05$ ).

Treatment 2 caused significant increases in seed yield (by 7.7\%), seed moisture (by $3.4 \%$ ), seed fat content (by 1.5\%), fat yield (by $9.2 \%$ ) and seed number per pod (by 17.3\%) and a significant reduction in straw yield (by 5.5\%) compared to combination 0 . Object 2 was characterized by a significantly higher number of seeds per pod (by $7.9 \%$ ) and weight of 1000 seeds (by 3.5\%).

The increase in seed yield found with treatments 1 and 2 resulted from an increase in the numbers of pods per plant and seeds per pod. On the other hand, the increase in fat yield was the result of an increase in the seed yield and fat content.

All the $p$-values based on ANOVA for the effect of treatment were significant $(p<0.05)$, which means the treatment had a strong effect on all studied traits. Moreover, most $p$ values for the interaction between treatment and environment were below 0.05 , which means that the effect of the treatment was modified by environmental conditions (soil and weather). Interactions of the most important agronomical traits, i.e., seed yield, fat 
content and fat yield, are presented in graphic form in Figure S1. Based on these results, we can conclude that the effect of the treatment depended on the environmental conditions (soil and weather) and was significant in about half of the environments. Most of the environments where a significant effect was observed were characterized by rather lower seed and fat yield and lower fat content.

\subsection{Variability of Plant Traits}

The highest variability was observed in the straw yield $(\mathrm{CV}=52.6 \%)$ and number of pods per plant $(\mathrm{CV}=50.7 \%$ ) (Table 3$)$. Such high variability of these traits can be caused by high individual variability of plants, which is dependent on plant density. A smaller plant density causes much stronger plant branching; on the contrary, if the plant density is higher, plants are less branched. This phenomenon is due to the many possibilities for rapeseed plants to compensate for branching at various plant densities. The lowest variability was observed for fat content in seeds $(\mathrm{CV}=4.3 \%)$, which is a trait less independent of environmental and agronomic conditions.

Table 3. Descriptive statistics for all experiments with winter rapeseed (2017-2019).

\begin{tabular}{|c|c|c|c|c|c|}
\hline Trait & Mean & Minimum & Maximum & $\begin{array}{c}\text { Standard } \\
\text { Deviation (SD) }\end{array}$ & $\begin{array}{c}\text { Coefficient of } \\
\text { Variation }(C V), \%\end{array}$ \\
\hline Seed yield at $9 \%$ moisture $\left(\mathrm{t} \mathrm{ha}^{-1}\right)$ & 3.99 & 2.33 & 6.37 & 0.79 & 19.69 \\
\hline Seed moisture $(\%)$ & 7.99 & 4.00 & 11.20 & 2.03 & 25.45 \\
\hline Fat content in seeds (\% d.m.) & 46.41 & 40.32 & 50.41 & 2.00 & 4.31 \\
\hline Fat yield $\left(\mathrm{kg} \mathrm{ha}^{-1}\right)$ & 1692 & 982 & 2885 & 387 & 22.85 \\
\hline Straw yield $\left(\mathrm{t} \mathrm{ha}^{-1}\right)$ & 3.85 & 2.30 & 13.40 & 2.02 & 52.55 \\
\hline Plant density at harvest (pcs. $\mathrm{m}^{-2}$ ) & 32.53 & 9.10 & 57.00 & 13.74 & 42.22 \\
\hline Number of pods (pcs. plant ${ }^{-1}$ ) & 307.9 & 113.6 & 929.0 & 156.2 & 50.73 \\
\hline Number of seeds per pod (pcs.) & 24.03 & 12.76 & 34.70 & 5.27 & 21.91 \\
\hline Weight of 1000 seeds $(\mathrm{g})$ & 4.75 & 2.00 & 7.40 & 0.89 & 18.82 \\
\hline Height of plants $(\mathrm{cm})$ & 142.56 & 108.40 & 188.90 & 19.91 & 13.96 \\
\hline
\end{tabular}

\section{Discussion}

The beneficial changes in the soil abundance of some macro- and microelements observed in the experiments confirm our other research [30,34]. Biopreparations containing the bacteria Bacillus spp., Thiobacillus spp., Azotobacter spp. and other plant growthpromoting rhizobacteria (PGPR) can maintain or even increase the soil organic carbon content in the arable layer of soil $[55,56]$. The results of previous studies proved the possibility of using P-solubilizing rhizobacteria as inoculants for canola, but P-solubilization was not the main reason for the positive effects on plant growth [57].

The beneficial effects of the use of growth activators and the bacterial preparation obtained in the experiments confirm the results obtained in the cultivation of other plant species. In the cultivation of sugar beet, the use of an identical combination with growth activators with the mineral nitrogen dose reduced by $30 \%$ resulted in increased root yield by $7.3 \%$ and technological sugar yield by $6.3 \%$ compared to the full nitrogen dose [34]. In the case of the combination of growth activators with the bacterial preparation, the increase was 11.5 and $13.4 \%$, respectively. Similar beneficial effects were obtained in the cultivation of maize, where the use of growth activators increased the grain yield by $2.9 \%$, and activators combined with a bacterial preparation increased the yield by $8.8 \%$ with a $30-40 \%$ reduction in the dose of mineral nitrogen compared to the combination with a full dose [30].

The use of PGPR had a positive effect on oilseed rape yield in other studies conducted with both the winter [55] and spring [23] forms. In the greenhouse, selected strains caused a 57\% increase in yield, and in field conditions, the yield increase was in the range of 6-13\% [15]. The inoculation of rapeseed with either Pseudomonas fluorescens or Pseudomonas putida had a positive effect on seed yield and reduced the negative effect of drought 
stress [58]. Individual application of either P. flourescens 169 or P. putida 108 showed better yields than the application of mixed strains [59]. Plant growth-promoting rhizobacteria (PGPR) can cause resistance to abiotic stress due to, e.g., drought and increased plant growth [60]. The rhizobacterium Azospirillum brasilense strain Ab-V5, presented as a growth promoter for canola plants, provided 2.6 times greater root development and increased plant height [61]. Azospirillum lipoferum mitigated the adverse effects of drought stress by improving the plant's physiological and biochemical processes [62].

\section{Conclusions}

The use of growth activators without additional products, or together with a bacterial preparation containing plant growth-promoting rhizobacteria with nitrogen fertilization, reduced by $30 \%$ significantly increased fat yield compared to the control treatment with a full dose of nitrogen fertilization. The increase in fat yield resulted from increases in both the seed yield and the fat content of seeds.

Assuming that the average dose of mineral nitrogen in the cultivation of winter oilseed rape in Poland is $200 \mathrm{~kg} \mathrm{ha}^{-1} \mathrm{~N}$, the use of growth activators alone or together with a bacterial preparation makes it possible to reduce fertilization with this component by approx. $60 \mathrm{~kg} \mathrm{ha}^{-1} \mathrm{~N}$. Taking into account the scale of oilseed rape production $(0.88$ million ha), this means savings of 52.8 thousand tonnes of mineral nitrogen per year. Therefore, introducing the researched solutions into agricultural practice would provide measurable benefits for the natural environment in Poland.

Supplementary Materials: The following are available online at https:/ / www.mdpi.com/2071-105 0/13/6/3562/s1, Table S1: Soil conditions before establishing an experiment with winter oilseed rapeseed (2016-2018), Table S2: Weather conditions during the growing spring season of winter oilseed rapeseed (2017-2019), Table S3: Characteristics of winter oilseed rape production technology in the experiment (2016/2017-2018/2019), Table S4: Soil conditions after the harvest winter oilseed rape (2017-2019), Figure S1: Means of seed yield (a), fat content (b) and fat yield (c) of variants of winter oilseed rape in different years and locations (environments).

Author Contributions: Conceptualization, A.A.; formal analysis, A.A.; investigation, A.A.; methodology, A.A.; supervision, A.A.; visualization, D.G.; writing-original draft, A.A. and D.G.; writingreview and editing, A.A. and D.G. All authors have read and agreed to the published version of the manuscript.

Funding: This research received no external funding.

Institutional Review Board Statement: Not applicable.

Informed Consent Statement: Not applicable.

Data Availability Statement: The data presented in this study are available on request from the corresponding author. The data are not publicly available due to ongoing unpublished research.

Conflicts of Interest: The authors declare no conflict of interest.

\section{References}

1. FAO. Food and Agriculture Data. Available online: http://www.fao.org/faostat/en/\#data/QC (accessed on 10 February 2021).

2. Polish Council of Ministers. Regulation of the Polish Council of Ministers on the adoption of the Action Program to reduce water pollution with nitrates from agricultural sources and to prevent further pollution. J. Laws Repub. Pol. 2020, 243.

3. Sieling, K.; Kage, H. Efficient N management using winter oilseed rape. A review. Agron. Sustain. Dev. 2010, 30, 271-279. [CrossRef]

4. Fridrihsone, A.; Romagnoli, F.; Cabulis, U. Environmental life cycle assessment of rapeseed and rapeseed oil produced in northern Europe: A Latvian case study. Sustainability 2020, 12, 5699. [CrossRef]

5. Jégo, G.; Sanchez-Pérez, J.M.; Justes, E. Predicting soil water and mineral nitrogen contents with the STICS model for estimating nitrate leaching under agricultural fields. Agric. Water Manag. 2012, 107, 54-65. [CrossRef]

6. Kloepper, J.W.; Zablotowicz, R.M.; Tipping, E.M.; Lifshitz, R. Plant growth promotion mediated by bacterial rhizosphere colonizers. In The Rhizosphere and Plant Growth; Keister, D.L., Cregan, P.B., Eds.; Kluwer Academic Publishers: Amsterdam, The Netherlands, 1991; pp. 315-326. 
7. Lucy, M.; Reed, E.; Glick, B.R. Applications of free living plant growth-promoting rhizobacteria. Anton. Leeuw. 2004, 86, 1-25. [CrossRef] [PubMed]

8. Liu, Y.; Gao, J.; Bai, Z.; Wu, S.; Li, X.; Wang, N.; Du, X.; Fan, H.; Zhuang, G.; Bohu, T.; et al. Unraveling Mechanisms and Impact of Microbial Recruitment on Oilseed Rape (Brassica napus L.) and the Rhizosphere Mediated by Plant Growth-Promoting Rhizobacteria. Microorganisms 2021, 9, 161. [CrossRef] [PubMed]

9. Konkolewska, A.; Piechalak, A.; Ciszewska, L.; Antos-Krzemińska, N.; Skrzypczak, T.; Hanć, A.; Sitko, K.; Małkowski, E.; Barałkiewicz, D.; Małecka, A. Combined use of companion planting and PGPR for the assisted phytoextraction of trace metals (Zn, Pb, Cd). Environ. Sci. Pollut. Res. 2020, 27, 13809-13825. [CrossRef]

10. Ren, X.M.; Guo, S.J.; Tian, W.; Chen, Y.; Han, H.; Chen, E.; Li, B.L.; Li, Y.Y.; Chen, Z.J. Effects of Plant Growth-Promoting Bacteria (PGPB) Inoculation on the Growth, Antioxidant Activity, Cu Uptake, and Bacterial Community Structure of Rape (Brassica napus L.) Grown in Cu-Contaminated Agricultural Soil. Front. Microbiol. 2019, 10, 1455. [CrossRef]

11. Kalyanasundaram, G.T.; Syed, N.; Subburamu, K. Recent developments in plant growth-promoting rhizobacteria (PGPR) for sustainable agriculture. In Recent Developments in Applied Microbiology and Biochemistry; Academic Press: Cambridge, MA, USA, 2021; Volume 2, pp. 181-192. [CrossRef]

12. Yagmur, B.; Gunes, A. Evaluation of the Effects of Plant Growth Promoting Rhizobacteria (PGPR) on Yield and Quality Parameters of Tomato Plants in Organic Agriculture by Principal Component Analysis (PCA). Gesunde Pflanz. 2021. [CrossRef]

13. Zhou, L.; Song, C.; Li, Z.; Kuipers, O.P. Antimicrobial activity screening of rhizosphere soil bacteria from tomato and genomebased analysis of their antimicrobial biosynthetic potential. BMC Genom. 2021, 22, 29. [CrossRef]

14. Chukwuneme, C.F.; Babalola, O.O.; Kutu, F.R.; Ojuederie, O.B. Characterization of actinomycetes isolates for plant growth promoting traits and their effects on drought tolerance in maize. J. Plant Interact. 2020, 15, 93-105. [CrossRef]

15. Kloepper, J.W.; Hume, D.J.; Scher, F.M.; Singleton, C.; Tipping, B.; Laliberté, M.; Frauley, K.; Kutchaw, T.; Simonson, C.; Lifshitz, R.; et al. Plant growth-promoting rhizobacteria on canola (rapeseed). Plant Dis. 1988, 72, 42-46. [CrossRef]

16. Van Peer, R.; Schippers, B. Plant growth responses to bacterization with selected Pseudomonas spp. strains and rhizosphere microbial development in hydroponic cultures. Can. J. Microbiol. 1988, 35, 456-463. [CrossRef]

17. Mei, R.; Chen, B.; Lu, S.; Chen, Y. Field application of field increasing bacteria (YIB). Chin. J. Microecol. 1990, 2, 45-49.

18. Hall, J.A.; Peirson, D.; Ghosh, S.; Glick, B.R. Root elongation in various agronomic crops by the plant growth promoting rhizobacterium Pseudomonas putida GR12-2. Isr. J. Plant Sci. 1996, 44, 37-42. [CrossRef]

19. Bertrand, H.; Nalin, R.; Bally, R.; Cleyet-Marel, J.C. Isolation and identification of the most efficient plant growth-promoting bacteria associated with canola (Brassica napus). Biol. Fertil. Soils 2001, 33, 152-156. [CrossRef]

20. Nosheen, A.; Bano, A.; Ullah, F. Nutritive value of canola (Brassica napus L.) as affected by plant growth promoting rhizobacteria. Eur. J. Lipid Sci. Technol. 2011, 113, 1342-1346. [CrossRef]

21. Ahmadi-Rad, S.; Gholamhoseini, M.; Ghalavand, A.; Asgharzadeh, A.; Dolatabadian, A. Foliar application of nitrogen fixing bacteria increases growth and yield of canola grown under different nitrogen regimes. Rhizosphere 2016, 2, 34-37. [CrossRef]

22. Yasari, E.; Mozaffani, S.; Ghasemi Chepi, O.; Farzin, N. Comparison of response of canola (Brassica napus L. cv. Hyola 401) to biofertilizer inoculation in optimal and delayed cropping dates. Cercet. Agron. Mold. 2016, 49, 53-66. [CrossRef]

23. Mamnabi, S.; Nasrollahzadeh, S.; Ghassemi-Golezani, K.; Raei, Y. Improving yield-related physiological characteristics of spring rapeseed by integrated fertilizer management under water deficit conditions. Saudi J. Biol. Sci. 2020, 27, 797-804. [CrossRef]

24. Sattari Nasab, R.; Pahlavan Yali, M.; Bozorg-Amirkalaee, M. Effects of humic acid and plant growth-promoting rhizobacteria (PGPR) on induced resistance of canola to Brevicoryne brassicae L. Bull. Entomol. Res. 2019, 109, 479-489. [CrossRef] [PubMed]

25. El-Howeity, M.A.; Asfour, M.M. Response of some varieties of canola plant (Brassica napus L.) cultivated in a newly reclaimed desert to plant growth promoting rhizobacteria and mineral nitrogen fertilizer. Ann. Agric. Sci. 2012, 57, 129-136. [CrossRef]

26. Naseri, R.; Maleki, A.; Naserirad, H.; Saber Shebibi, S.; Omidian, A. Effect of plant growth promoting rhizobacteria (PGPR) on reduction nitrogen fertilizer application in rapeseed (Brassica napus L.). Middle East J. Sci. Res. 2013, 14, 213-220. [CrossRef]

27. Basu, A.; Prasad, P.; Das, S.N.; Kalam, S.; Sayyed, R.Z.; Reddy, M.S.; El Enshasy, H. Plant Growth Promoting Rhizobacteria (PGPR) as Green Bioinoculants: Recent Developments, Constraints, and Prospects. Sustainability 2021, 13, 1140. [CrossRef]

28. Mushtaq, Z. PGPR: Present role, mechanism of action and future prospects along bottlenecks in commercialization. EQA Intern. J. Environ. Qual. 2020, 41, 9-15. [CrossRef]

29. Leontidou, K.; Genitsaris, S.; Papadopoulou, A.; Kamou, N.; Bosmali, I.; Matsi, T.; Madesis, P.; Vokou, D.; Karamanoli, K.; Mellidou, I. Plant growth promoting rhizobacteria isolated from halophytes and drought-tolerant plants: Genomic characterisation and exploration of phyto-beneficial traits. Sci. Rep. 2020, 10, 14857. [CrossRef] [PubMed]

30. Artyszak, A.; Gozdowski, D. Is It Possible to Replace Part of the Mineral Nitrogen Dose in Maize for Grain by Using Growth Activators and Plant Growth-Promoting Rhizobacteria? Agronomy 2020, 10, 1647. [CrossRef]

31. Kadziuliene, Z.; Feiziene, D.; Leistrumaite, A.; Semaskiene, R. Peculiarities of some legumes and cereals under organic farming system. NJF-Seminar 369. Organic farming for a new millennium-Status and future challenges. Published by Nordic Association of Agricultural Scientists (NJF), Section I: Soil, Water and Environment Swedish University of Agricultural Sciences Alnarp, Sweden 15-17 June 2005. NJF Rep. 2005, 1, 103-106.

32. Pekarskas, J.; Vilkenyte, L.; Sileikiene, D.; Cesoniene, L.; Makarenko, N. Effect of organic nitrogen fertilizers Provita and fermentator Penergetic-K winter Wheat and on soil quality. In Proceedings of the 8th International Conference, Environmental Engineering, Vilnius, Lithuania, 19-20 May 2011; pp. 248-254. 
33. Jakiene, E.; Venskutonis, V.; Liakas, V. Fertilization of sugar beet root with ecological fertilizers. Agron. Res. 2009, 7, 269-276.

34. Artyszak, A.; Gozdowski, D. The Effect of Growth Activators and Plant Growth-Promoting Rhizobacteria (PGPR) on the Soil Properties, Root Yield, and Technological Quality of Sugar Beet. Agronomy 2020, 10, 1262. [CrossRef]

35. Jakiene, E.; Venskutonis, V.; Mickevicius, V. The effect of additional fertilization with liquid complex fertilizers and growth regulators on potato productivity. Scientific works of the Lithuanian Institute of Horticulture and Lithuanian University of Agriculture. Sodininkystè Daržininkystè 2008, 27, 259-267.

36. De Souza, A.A.; de Almeida, F.Z.; Alberton, O. Growth and yield of soybean with Penergetic application. Sci. Agrar. 2017, 18, 95-98.

37. Brito, O.R.; Dequech, F.K.; Brito, R.M. Use of Penergetic products P and K in the snap bean production. Annu. Rep. 2012, 55, 279-280.

38. Jankauskienè, J.; Survilienè, E. Influence of growth regulators on seed germination energy and biometrical parameters of vegetables Scientific works of the Lithuanian Institute of Horticulture and Lithuanian University of Agriculture. Sodininkyste Daržininkystè 2009, 28, 69-77.

39. Nascente, A.S.; Cobucci, T. Phosphate fertilization in the soil and Penergetic application in the grain yield of common bean. Soils Embrace Life and Universe. In Proceedings of the 20th World Congress of Soil Science, Jeju, Korea, 8-13 June 2014.

40. Franco Junior, K.S.; Terra, A.B.C.; Teruel, T.R.; Mantovani, J.R.; Florentino, L.A. Effect of cover crops and bioactivators in coffee and chemical properties of soil. Coffee Sci. Lavras 2018, 13, 559-567.

41. IUSS Working Group WRB. World Reference Base for Soil Resources 2014. In International Soil Classification System for Naming Soils and Creating Legends for Soil Maps; Update 2015; World Soil Resources Report 106; FAO: Rome, Italy, 2015.

42. PKN. PN-ISO 10390:1997. Soil Quality—pH Determination; Polish Committee for Standardization: Warsaw, Poland, 1997.

43. Regional Agrochemical Station. Research Procedure of the Regional Agrochemical Station in Warsaw; No. PB 01 ed.; Regional Agrochemical Station: Warsaw, Poland, 2009.

44. Regional Agrochemical Station. Research Procedure of the Regional Agrochemical Station in Warsaw; No. PB 46 ed.; Regional Agrochemical Station: Warsaw, Poland, 2017.

45. PKN. Polish Standard PN-R-04023:1996. Agro-Chemical Analysis of Soil-Determination of Available Phosphorus. Content in Mineral Soils; Polish Committee for Standardization: Warsaw, Poland, 1996.

46. PKN. Polish Standard PN-R-04022:1996/Az1:2002. Agro-Chemical Analysis of Soil_Determination of Available Potassium Content in Mineral Soils; Polish Committee for Standardization: Warsaw, Poland, 1996.

47. PKN. Polish Standard PN-R-04020:1994/Az1:2004. Agro-Chemical Analysis of Soil_Determination of Available Magnesium Content in Mineral Soils; Polish Committee for Standardization: Warsaw, Poland, 1994.

48. PKN. Polish Standard PN-93/R-04018. Agro-Chemical Analysis of Soil. Determination of Available Boron; Polish Committee for Standardization: Warsaw, Poland, 1993.

49. PKN. Polish Standard PN-92/R-04017. Agro-Chemical Analysis of Soil. Determination of Available Copper; Polish Committee for Standardization: Warsaw, Poland, 1992.

50. PKN. Polish Standard PN-R-04021:1994. Agro-Chemical Analysis of Soil. Determination of Available Iron; Polish Committee for Standardization: Warsaw, Poland, 1994.

51. PKN. Polish Standard PN-93/R-04019. Agro-Chemical Analysis of Soil. Determination of Available Manganese; Polish Committee for Standardization: Warsaw, Poland, 1993.

52. PKN. Polish Standard PN-92/R-04016. Agro-Chemical Analysis of Soil. Determination of Available Zinc; Polish Committee for Standardization: Warsaw, Poland, 1992.

53. PKN. Polish Standard PN-76/R-64753. Determination of Raw Fat; Polish Committee for Standardization: Warsaw, Poland, 1976.

54. PKN. Polish Standard PN-EN ISO 520. Cereals and Pulses-Determination of the Mass 1000 Grains; Polish Committee for Standardization: Warsaw, Poland, 2010.

55. Juknevičius, D.; Kriaučiūnienè, A.; Jasinskas, A.; Šarauskis, E. Analysis of Changes in Soil Organic Carbon, Energy Consumption and Environmental Impact Using Bio-Products in the Production of Winter Wheat and Oilseed Rape. Sustainability 2020, $12,8246$. [CrossRef]

56. Benidire, L.; Madline, A.; Pereira, S.I.A.; Castro, P.M.L.; Boularbah, A. Synergistic effect of organo-mineral amendments and plant growth-promoting rhizobacteria (PGPR) on the establishment of vegetation cover and amelioration of mine tailings. Chemosphere 2021, 262, 127803. [CrossRef]

57. De Freitas, J.; Banerjee, M.; Germida, J. Phosphate-solubilizing rhizobacteria enhance the growth and yield but not phosphorus uptake of canola (Brassica napus L.). Biol. Fertil. Soils 1997, 24, 358-364. [CrossRef]

58. Arvin, P.; Vafabakhsh, J.; Mazaheri, D.; Noormohamadi, G.; Azizi, M. Study of drought stress and plant growth promoting rhizobacteria (PGPR) on yield, yield components and seed oil content of different cultivars and species of brassica oilseed rape. Ann. Biol. Res. 2012, 3, 4444-4451.

59. Arvin, P.; Bakhsh, J.V.; Mazaheri, D. Study of Plant Growth Promoting Rhizobacteria (PGPR) and drought on physiological traits and ultimate yield of cultivars of oilseed rape (Brassica spp. L.). Agroecology 2018, 9, 1208-1226.

60. Arvin, P.; Vafabakhsh, J. Study of drought and plant growth promoting rhizobacteria (PGPR) on radiation use efficiency and dry matter partitioning into pod in different cultivars of Brassica oilseed rape. J. Agroecol. 2016, 8, 134-152. 
61. Gomes, D.G.; Radi, A.J.; Aquino, G.S. Growth-promoting bacteria change the development of aerial part and root system of canola. Semin. Ciênc. Agrár. Londrina 2018, 39, 2375-2384. [CrossRef]

62. Saeed, M.; Ilyas, N.; Mazhar, R.; Bibi, F.; Batool, N. Drought mitigation potential of Azospirillum inoculation in canola (Brassica napus). J. Appl. Bot. Food Qual. 2016, 89, 270-278. [CrossRef] 